Tumors situated above $6 \mathrm{~cm}$ should be treated by anterior resection. Rectal continence improves over the first year after deep anterior resection. Disturbances of the lower urinary tract and sexual impotence are more frequent after excision of the rectum. In patients with no involvement of the lymph nodes, the 5-year survival rate is similar after excision as after resection of the rectum.

Key words: Colostamy, continent - Cancer, rectal - Excision - Resection.

Zusammenfassung. 1975 haben wir 120 Resektionen oder Exstirpationen wegen Rectumcarcinom durchgeführt. Bei Tumoren unterhalb $6 \mathrm{~cm}$ ist die Exstirpation mit Anlegen einer kontinenten Magnetringkolostomie angezeigt. Höher gelegene Tumore werden sphinctererhaltend reseziert.

Die Kontinenz nach tiefer Resektion verbessert sich im Laufe des ersten Jahres. Blasenstörungen und Potenzstörungen sind nach Resektion signifikant seltener. Die 5-Jahres-Überlebenszeit ist nach Resektion oder Exstirpation gleich, wenn bei der Operation die Lymphknoten tumorfrei waren.

Schliisselwörter: Rectumcarcinom - Exstirpation - Resektion - Magnetringcolostomie.

\title{
168. Die Kompressionsstenose der Arteria coeliaca, Ursache, Diagnostik, Klinik, Operationsergebnis
}

\author{
H. G. Beger, M. Meves, D. Apitsch, E. Kraas und R. Bittner \\ Chirurgische Universitätsklinik und Poliklinik, Klinikum Charlottenburg, Freie Universität Berlin
}

\section{Celiac Artery: Compression Syndrome}

Summary. Compression of the celiac artery (A.C.), a syndrome whose incidence is rising steadily, is caused by the ligamentum arcuatum medianum or neurofibromatosic ganglion tissue. Patients with an extreme stenosis or occlusion of the A.C. suffer from pain in the upper abdomen (92\%), abdominal vascular murmur $(87 \%)$, loss of weight $(56 \%)$ and nausea and vomiting $(52 \%)$. The pronounced collateral blood flow from the A. mesenterica superior is a strikingly obvious feature of the angiograph. According to the authors' own experience with 32 patients suffering from compression of the A.C., the only indication for an operation is extreme stenosis or occlusion accompanied by pain in the upper abdomen observed over a long period.

Key words: Artery, celiac - Pain, abdominal - Tissue, neurofibromatosic - Diaphragma.

Zusammenfassung. Die Kompression der Art. coeliaca (A.C.) - ein zunehmend häufiger werdendes Krankheitsbild - wird verursacht durch das Ligamentum arcuatum medianum oder neurofibromatöses Gangliongewebe. Patienten mit hochgradiger Stenose oder Verschluß der A.C. haben Oberbauchschmerzen $(92 \%)$, abdominelles Gefäßgeräusch ( $87 \%$ ), Gewichtsverlust $(56 \%)$, Brechreiz und Erbrechen (52\%). Angiographisch fällt der ausgeprägte kollaterale Blutzufluß aus der A. mesenterica superior auf. Nach der eigenen Erfahrung mit 32 Patienten, die eine Kompression der A.C. hatten, besteht eine Op.-Indikation nur bei hochgradiger Stenose oder Verschluß und gleichzeitig über längere Zeit objektivierbaren Oberbauchschmerzen.

Schlïsselwörter: Art. coeliaca - Oberbauchschmerzen - Diaphrama - Ganglion coeliacum. 